\title{
Locational advantage and the impact of scale: Comparing local and conventional fruit and vegetable transportation efficiencies
}

\author{
Chuck Grigsby a* and Chad Hellwinckel b \\ University of Tennessee
}

Submitted December 3, 2015 / Revised February 20, 2016 / Accepted February 20, 2016 /

Published online June 20, 2016

Citation: Grigsby, C., \& Hellwinckel, C. (2016). Locational advantage and the impact of scale: Comparing local and conventional fruit and vegetable transportation efficiencies. Journal of Agriculture, Food Systems, and Community Development, 6(3), 121-140. http://dx.doi.org/10.5304/jafscd.2016.063.010

Copyright (C) 2016 by New Leaf Associates, Inc.

\begin{abstract}
Some have suggested that in order for local foods to reach broader consumer segments and become price-competitive with foods sold in mainstream market channels, local farmers need to scale up their production and distribution operations to match the efficiencies of the conventional food system. In this study, we take a first step in evaluating how scaling up production and distribution could make locally produced foods more competitive with the conventional food system. We compare the transportation efficiencies of the conventional and local fruit and vegetable transportation networks in Knoxville, Tennessee,

a* Corresponding author: Chuck Grigsby, Department of Agricultural \& Resource Economics, 310 Morgan Hall, 2621 Morgan Circle; University of Tennessee; Knoxville, Tennessee 37996-4519 USA; +1-865-368-3519; cgrigsby@,vols.utk.edu

${ }^{\mathrm{b}}$ Chad Hellwinckel, Department of Agricultural \& Resource Economics, 310 Morgan Hall, 2621 Morgan Circle; University of Tennessee; Knoxville, Tennessee 37996-4519; +1-865-9745006; chellwin@utk.edu
\end{abstract}

and determine the Knoxville-area food system's competitive transportation zones, defined as the region in which local farmers' shorter travel distances to market give them a locational advantage in transportation over their long distance, conventional food supply chain competitors. We analyze the extent to which local farmers' scales of production and distribution affect their transportation efficiencies, and we investigate factors that could improve their competitiveness with conventional distribution networks. We find that farms located within 25 miles $(40 \mathrm{~km})$ of the downtown market tended to deliver their produce to market at least as efficiently as conventionally distributed foods from California. More distant farms needed to scale up their production and distribution operations to remain within the competitive transportation zones. Investigating travel distance thresholds could provide policy-makers with useful information in planning land use and infrastructure investment projects for local food systems and in 
designating sustainable geographic boundaries for foodsheds and local food economies.

\section{Keywords}

food distribution, food miles, local and regional food systems, location theory, sustainable agriculture, transportation efficiency

\section{Introduction and Literature Review}

Analysts of local food supply chains often suggest scaling up the local food system's transportation network to more effectively compete with the scale efficiencies of the conventional food transportation system, and in turn propel local foods beyond higher-priced niche markets (Bittner, DayFarnsworth, Miller, Kozub, \& Gollnik, 2011; DayFarnsworth, McCown, Miller, \& Pfeiffer, 2009; Day-Farnsworth \& Miller, 2014; King et al., 2010). The objective of this research is to improve the understanding of how local farmer transportation efficiency compares with conventionally transported foods in a midsized, southeastern U.S. city: Knoxville, Tennessee. Using Hotelling's location theory framework (1929), our goal is to determine local farmers' locational advantage in transportation: the geographical boundary, or threshold, within which local producers can deliver their fresh produce to market at least as efficiently as the conventional fruit and vegetable transportation system. In our analysis, we investigate the impact of changes in production and transportation scales on local food distribution efficiency, and develop a model to demonstrate how increasing key production and transportation scale factors affect local farmers' travel distance thresholds against conventionally shipped foods. Analyzing the competitive transportation zones in other communities could help policy-makers and planners develop more sustainable and resilient local food economies.

Production of fruits and vegetables in the U.S. has become increasingly limited to the states of California, Texas, and Florida due to their natural competitive advantage. The geographical and climatological characteristics of these states are optimal for large-scale, year-round production of most fruits and vegetables (Lucier, Pollack, Ali, \& Perez, 2006; Paggi, Noel, Yamazaki, Hurley, \&
McCullough, 2012; U.S. Department of Agriculture, National Agricultural Statistics Service [USDA NASS], 2014). These three states rank in the top 10 in freight transportation of fruits and vegetables by volume in the United States (USDA Agricultural Marketing Service [USDA AMS], 2014a). California alone accounts for 65 and 48 percent of the nation's fruit and nut, and vegetable production, respectively, and is the nation's leading producer of nearly 80 crop and livestock commodities (USDA NASS, 2013).

This concentration of production promotes the establishment of other industry-specific infrastructure, services, and technical skills that in turn benefit members in the regional industry cluster (Isard \& Peck, 1954; Marshall, 1920; McCann, 2013; Ohlin, 1934). California, Texas, and Florida, for example, also rank among the top 10 states in food and beverage manufacturing (U.S. Census Bureau, 2010). Specialization throughout the entire supply chain spurs the development of costreducing technologies that engender economies of scale, and thus the competitive gap widens (Chandler \& Hikino, 2009).

Transportation is a component of the fruit and vegetable supply chain that has experienced significant technological advances through the development of more efficient refrigerated trucking devices that employ remote monitoring and global positioning systems (GPS) to help maintain produce quality during transit (Coyle, Hall, \& Ballenger, 2001; Kaufman, Handy, McLaughlin, Park, \& Green, 2000; Paggi et al., 2012). Technological improvements have permitted growers in more productive agricultural areas, despite their geographical separation from final consumer markets, to effectively exploit food supply chains that rely on long distance transportation (Coyle et al., 2001; Wang, Coyle, Gehlhar, \& Vollrath, 2000). Much of California's early economic development focused on reducing the shipping costs of the state's staple agricultural crops via technological advances in long distance transportation (North, 1955). Long distance freight transportation of fresh fruits and vegetables by truck has intensified more rapidly than the modes used to ship other agricultural commodities (Coyle et al., 2001). In the United States, most perishable produce is hauled from 500 
to 3,000 miles ( 805 to $4,828 \mathrm{~km}$ ) before reaching consumers, using special packaging and controlledatmosphere shipping technology (Ashby, 1995; Huang, 2004).

Some food analysts are concerned with the energy, environmental, social, and economic implications of the increasing distance food travels (Heller \& Keoleian, 2003; Mundler \& Rumpus, 2012; Paxton, 1994). Researchers use life-cycle analysis to estimate the energy consumed for long distance food transportation, and the data are often compared with the energy consumed in local food transportation networks (Coley, Howard, \& Winter, 2009; Jones, 2002; Sim, Barry, Clift, \& Cowell, 2007; Wallgren, 2006). Sourcing produce from distant origins and relying on long distance truck shipments has been a successful strategy during periods of low energy prices (Hendrickson, 1994). However, under a scenario with high fuel costs, the current supply network could become a high-cost structure for U.S. food distribution (Casavant et al., 2010).

Despite longer travel distances and the transportation sector's vulnerability to fuel price volatility, some researchers suggest that economies of scale make the conventional (long distance) production and transportation system of fruits and vegetables more energy-efficient per unit of produce shipped compared to local food distribution networks (Avetisyan, Hertel, \& Sampson, 2014; Coley et al., 2009; Mariola, 2008; Saunders, Barber, \& Sorenson, 2009; Schlich \& Fleissner, 2005). Conventional shipping hauls thousands of pounds of fruits and vegetables in a single semi-truck load, and thus the fuel use per unit of produce shipped is often minimal (Mariola, 2008). Similarly, Avetisyan et al. (2014) and Saunders, Barber, and Taylor (2006) emphasize the importance of considering more than the fuel used during food transportation because the comparative advantage in production in distant locations may outweigh the benefits of lower fuel consumption in a local food distribution system.

Transportation of locally grown food, in contrast, may be less efficient than the conventional system in terms of energy use per unit of product shipped, as small- and midsized local vendors bring less produce to market, and therefore have lower fuel use efficiencies despite traveling fewer miles to distribute their produce (Low \& Vogel, 2011). Although sourcing food locally results in fewer total food miles, the actual fuel consumed in local transportation is typically higher on a per-unit basis because conventional supply chains transport larger volumes of produce (King et al., 2010). As local food distribution systems are still evolving, and conventional food supply chains have had more time to develop their scale efficiencies (King, Gómez, \& DiGiacomo, 2010; Martinez et al., 2010), U.S. food system researchers investigating local food distribution often suggest scaling up the local food system's transportation network to create a local food supply chain that has efficiencies similar to the conventional food transportation system, capitalizing on local farmers' proximity to mainstream consumer markets (Bittner et al., 2011; Day-Farnsworth et al., 2009; Day-Farnsworth \& Miller, 2014; Etemadnia, Goetz, Canning, \& Tavallali, 2015; King et al., 2010).

\section{Hotelling's Spatial Competition Model}

The spatial competition model (1929), first developed by Launhardt (1885) and later adopted by Hotelling and then Palander (1935) (Fujita, 2010), conceptualizes the idea that scaling up production and transportation operations of small-scale local farmers can improve their food distribution efficiency, which in turn can provide greater marketing opportunities to local producers.

Applying the Hotelling model to the topic at hand, assume the existence of a two-dimensional space in which farmers from two regions sell identical fruit and vegetable baskets (Figure 1) (McCann, 2013). Let the horizontal axis represent distance and the vertical axis indicate product price. Region 1 farmers are located at $R 1$, while Region 2 farmers are located at $R 2$, and therefore the farmers are separated by distance R1-R2. Because Region 1 farmers have a natural productive advantage in growing fruits and vegetables relative to Region 2 and have increasing returns to production, the Region 1 market price for the fresh produce basket at $R 1, p_{R 1}$, is below the price for the fresh produce basket of the less efficient Region $2, p_{R 2_{0}}$.

Consumers are homogenously distributed 


\section{Figure 1. Hotelling's Two-Region Spatial Competition Model and the Effect of Increased Production} and Transportation Efficiencies

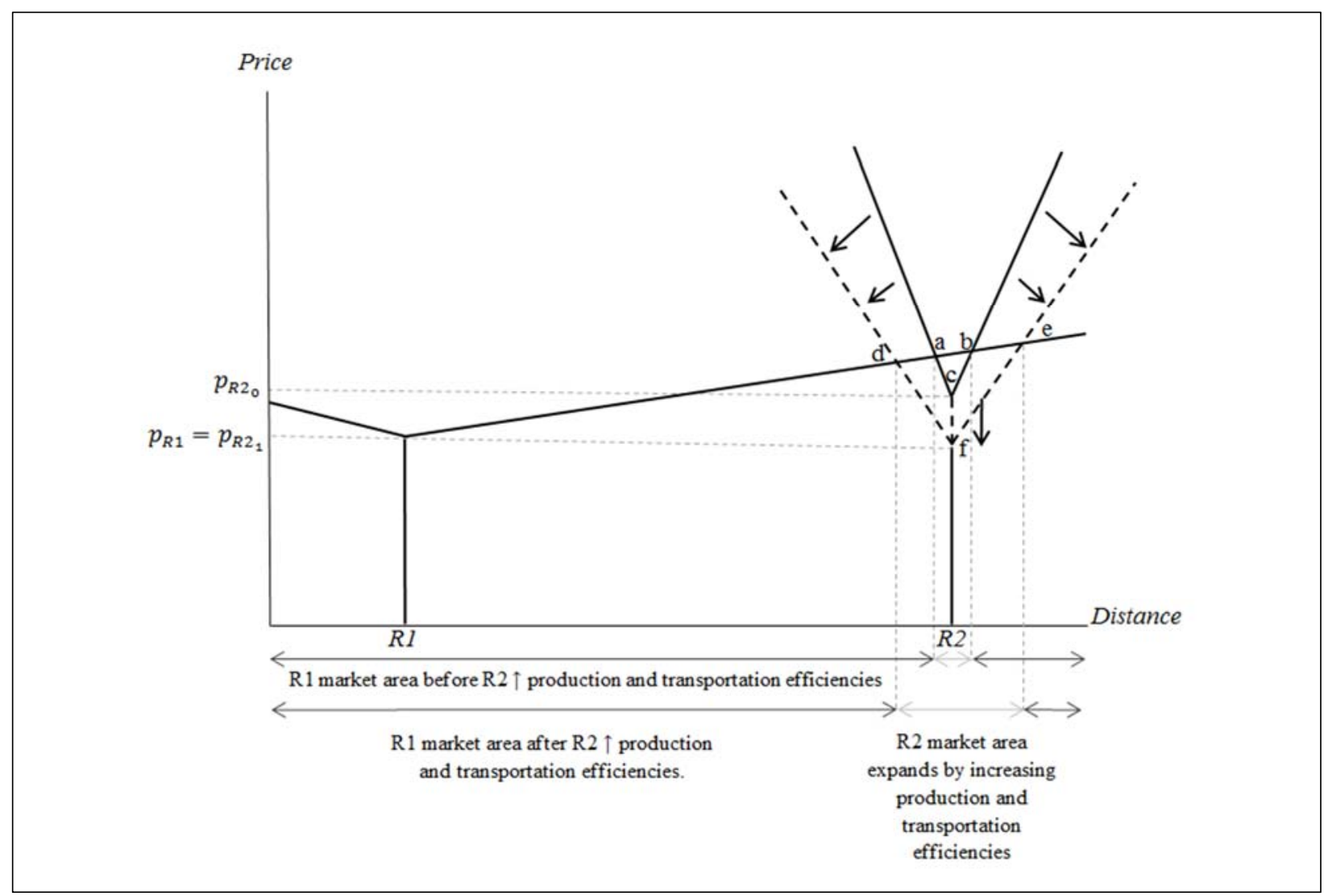

across space and demand exactly one fresh produce basket per period, regardless of price (Eiselt \& Laporte, 1989). Because both regions produce the same fresh produce basket, consumers are indifferent between purchasing baskets from farmers in Region 1 or Region 2, and thus purchase from the producer with the lowest delivery price. To deliver fresh produce baskets to consumers, Region 1 and Region 2 farmers incur transportation costs that increase at constant rates per unit of distance, $t_{R 1}$ and $t_{R 2}$, respectively. Both $t_{R 1}$ and $t_{R 2}$ are functions of transportation efficiency and exogenously determined fuel prices. The slope of the transport cost function for producers in Region 1 is flatter than in Region 2, reflecting the Region 1 supply chain's economies of scale in transporting fresh produce baskets.

From Figure 1, it is apparent that producers from Region 1 control most of the fruit and vegetable market, while the market area of Region
2 farmers is limited to markets with shorter travel distances. Their low production costs and high transportation efficiencies allow Region 1 farmers to outcompete Region 2 farmers in sales to consumer markets that are closer in distance to Region 2 farmers. Though Region 2 producers have a potential locational advantage in delivering fruit and vegetable baskets to these nearby markets, their small production and transportation scales constrain their market area. Region 2 farmer profits are limited to area $a b c$.

In contrast to Hotelling's spatial competition model, in which firms change location to gain monopoly power (McCann, 2013), given the immobility of farmland, farmers in Region 1 and 2 cannot move their production locations to gain market area over their competition. On the other hand, farmers in Region 1 or Region 2 can expand their market area by improving their production and transportation efficiencies, thereby reducing 
production and transportation costs relative to farmers in the other region. Indeed, the conventional food supply chain is characterized by the lowering of production and transportation costs to sell its products globally at lower prices than the same items sourced locally. The small production and distribution scales of many local farmers constrain their competitiveness to nearby markets, forcing them to adopt niche marketing strategies.

The Hotelling framework suggests that, just as Region 1 farmers have lowered production and transportation costs by increasing the size of their operations to generate economies of scale, farmers in Region 2 can recoup part of their market by similarly scaling up production and transportation networks. By doing so, Region 2 farmers can gain a competitive edge in the markets for which they have an improved locational advantage in transporting fresh produce baskets. The dashed production and transportation functions in Figure 1 show that increasing on-farm productivity in Region 2 to the level of Region 1 reduces the price in Region 2 to the Region 1 level, $p_{R 1}=p_{R 2_{1}}$, while improving transportation efficiency flattens the Region 2 transportation cost function. Implementing such a strategy would expand the competitive market area of Region 2 farmers and increase profits by the areas dacf and $e b c f$. In this study, we use the Hotelling framework to analyze how increasing the scale of local farmers' production and transportation operations improves their transportation efficiencies, and in turn flattens their transportation cost curves to regain market area. An analysis of how scaling up local farmers' production operations affects their production efficiencies and their competitive market area is left for future research.

\section{Methods and Procedures}

\section{Local Farmer Survey}

We conducted an in-person interview survey of farmers selling fruits and vegetables in direct-toconsumer local markets in Knox County, Tennessee, to accomplish the objectives. The downtown farmers market in Knoxville, Tennessee, was chosen as the primary interview site because it is one of the largest live markets in the east Tennessee region, and therefore attracts a mix of nearby, in-county farms and more distant, out-ofcounty farms. All 21 of the farmers participating in the downtown farmers market were interviewed. To increase the size of the survey, eight farmers selling produce in two other popular Knox County farmers markets were also interviewed, for a total of 29 surveyed farms. Because it is common for farmers to sell produce in more than one farmers market, in these periphery markets only farmers that were not vendors at the downtown market were solicited to participate in the survey. The survey was conducted during the summer months of June, July, and August 2014. At the end of the survey period all farmers from the three Knox County markets had been interviewed. Farmers were contacted during market hours. The survey was limited to farmers selling fresh produce.

We used research methods from life-cycle analysis, transportation economics, and local food case-study literature in formulating and conducting the survey (Friedlaender \& Spady, 1980; Hummels, 2007; King, Hand, \& DiGiacomo, 2013; Moneta, 1959; Mundler \& Rumpus, 2012; Wang et al., 2000). For life-cycle analysis accounting, the research unit of interest should be clearly defined (Rebitzer et al., 2004). In the case of collecting transportation fuel use efficiency information from local farmers, the primary unit of interest was gallons of fuel consumed per 100 pounds $(45 \mathrm{~kg})$ of produce delivered to market $(\mathrm{g} / \mathrm{cwt})$. The surveyed farmers were asked to provide all information that would affect the calculation of $\mathrm{g} / \mathrm{cwt}$.

\section{Estimation of Fuel Use Efficiency from Survey Data} Following Wallgren (2006), the interviewer collected farm addresses and a detailed description of the route taken to market, including any habitual stops, detours, additional deliveries, or side roads used during transit. The total distance traveled to the market in which the farmer was interviewed was estimated from this information. The farmer's return travel distance was included in the total distance calculation to account for the fuel consumption of partial and empty loads (Kaplin, 2012). The total mileage was verified using Google Maps (2014) and geographical information system (GIS) software (ArcGIS for Desktop Version 10.3). All 29 surveyed farmers indicated that the 
Table 1. Description of Local Farmer Survey Data

\begin{tabular}{ll}
\hline Variable & Description \\
\hline Distance & Two-way travel distance to transport produce to market (miles) \\
\hline Truckload & Truckload weight of fruits and vegetables per trip to the farmers market (Ibs.) \\
\hline MPG & Vehicle fuel economy (miles per gallon) \\
\hline Boxtruck & Equals 1 if produce delivered using a box truck; 0 otherwise* \\
\hline Gallons & Gallons of fuel per trip to market \\
\hline g/cwt & Gallons of fuel per 100 pounds of produce shipped to market \\
\hline Acres & Number of acres planted in fruits and vegetables for local food market sales* \\
\hline Organic & Equals 1 if produce was certified organic or naturally grown; 0 otherwise* \\
\hline AcresOrg & Interaction term between Acres and Organic* \\
\hline Mktchannels & $\begin{array}{l}\text { Number of marketing channels used per week; participating in multiple farmers markets ( } \\
\text { community supported agriculture (CSA) shares, roadside farm stand, delivery to restaurants and } \\
\text { wholesalers, or operating a pick-your-own enterprise, are respectively counted as a marketing } \\
\text { channel* }\end{array}$ \\
\hline
\end{tabular}

* Used for regression analysis

sole purpose of their trip to market was to sell their produce.

Information on farmer vehicle model, year, drivetrain, and fuel type was collected, along with the truckload weight (lbs.) of produce shipped to the farmers market. The interviews were administered during the peak growing months in which the heaviest fresh produce (e.g., tomatoes, squash, melons, and root crops) was marketed by local farmers. Therefore, calculations of $\mathrm{g} / \mathrm{cw}$ likely reflect greater fuel efficiency estimates because of heavier-than-average truckload weights per trip. If the farmer could not provide a reliable estimate of truckload weight, the truckload weight per trip was estimated by weighing the farm stand's different produce boxes (Wallgren, 2006).

Each farmer's vehicle fuel economy, measured in miles per gallon (MPG; 1 gallon=3.8 liters), was estimated using the U.S. Department of Energy's (2014) vehicle fuel efficiency calculator. Farmer $i$ 's fuel consumption per trip to market $\left(G_{i}\right)$ was calculated as the two-way distance from farm to market divided by the MPG of the farmer's vehicle. To estimate $\mathrm{g} / \mathrm{cwt}, G_{i}$ was divided by the
Table 2. Descriptive Statistics for Local Farmer Survey Data

\begin{tabular}{lcccc}
\hline Variable & Mean & Median & Min. & Max. \\
\hline Distance (miles) & 75.40 & 56.40 & 9.4 & 198.5 \\
\hline Truckload (Ibs.) & 768.98 & 760.30 & 100 & 4050 \\
\hline MPG & 14.61 & 14 & 9.21 & 23 \\
\hline Boxtruck & 0.31 & 0 & 0 & 1 \\
\hline Gallons & 5.56 & 4 & 0.47 & 19.85 \\
\hline g/cwt & 0.96 & 0.59 & 0.06 & 3.78 \\
\hline Acres & 3.81 & 2 & 0.25 & 25 \\
\hline Organic & 0.31 & 0 & 0 & 1 \\
\hline Mktchannels & 1.86 & 2 & 0 & 4 \\
\hline
\end{tabular}

farmer's estimated truckload weight and multiplied by 100 pounds $(45 \mathrm{~kg})$. The term $\mathrm{g} / \mathrm{cwt}$ measures local farmer transportation fuel use efficiency and provides a baseline image of local food distribution efficiency. This estimate provides an understanding of how travel distance to market, MPG, and truckload weight affect transportation energy use efficiencies. Descriptions of the data collected from the survey and descriptive statistics associated with those data are presented in Tables 1 and 2, respectively. These data were used throughout the analysis. 


\section{Comparing Local Farmer and Conventional Fuel Use Efficiencies}

The $\mathrm{g} / \mathrm{cwt}$ estimates for the local surveyed farmers were compared with the transportation fuel use efficiencies (i.e., g/cwt estimates) of the conventional, long distance distribution systems for produce shipped from Florida, Texas, and California. Conventional $\mathrm{g} / \mathrm{cwt}$ estimates were developed from data provided by the USDA AMS weekly truck rate reports for fresh produce (Agricultural Refrigerated Truck Quarterly) (USDA AMS, 2014b), and other food distribution studies (Casavant et al., 2010; King et al., 2010). The AMS reports that conventional semi-trucks transporting fruits and vegetables haul 39,000 pounds $(17,690 \mathrm{~kg})$ of fresh produce, on average. The U.S. Department of Transportation (DOT) (2014) estimates that semitruck fuel efficiency is approximately 5.7 MPG, while other studies assume that conventional semitruck fuel economy ranges between 5.3 MPG and 6.1 MPG (King et al., 2010; Paggi et al., 2012; Pirog, Van Pelt, Enshayan, \& Cook, 2001). The DOT's estimate is the fuel economy used in this study. The travel distances for the conventional transportation systems assumed shipping points from Palm Beach County, Florida; Hidalgo County, Texas; and San Joaquin Valley, California. The terminal market for all three shipping points was the downtown Knoxville farmers market. Google Maps (2014) was used to approximate the total distance traveled from each shipping point to the terminal market. Distances for the Florida, Texas, and California shipping points are 818 miles $(1,316 \mathrm{~km}), 1,333$ miles $(2,145 \mathrm{~km})$, and 2,338 miles $(3,763 \mathrm{~km})$, respectively. ${ }^{1}$

The $\mathrm{g} / \mathrm{cwt}$ for the local farmers were compared in two ways with the $\mathrm{g} / \mathrm{cwt}$ of produce shipped from Florida, Texas, and California. First,

\footnotetext{
${ }^{1}$ Two-way travel distances are included in the local farmer $\mathrm{g} / \mathrm{cwt}$ estimates, whereas one-way travel distances are assumed for the three conventional supply chains (Kaplin, 2012). Conventional semi-trucks transporting fruits and vegetables over long distances typically return with full truckloads of other products to maximize efficiency. The interviewed local farmers, on the other hand, did not report any backhaul activity.

${ }^{2}$ Case studies related to scaling up local food distribution are most often oriented toward farm produce aggregation and
}

they were compared by listing the $\mathrm{g} / \mathrm{cwt}$ of all 29 interviewed local farmers and the $\mathrm{g} / \mathrm{cwt}$ of the three distant shipping points on the same graph. The percentages of local farmers with lower $\mathrm{g} / \mathrm{cwt}$ estimates were calculated relative to the fuel use efficiency of transporting produce from each of the distant shipping points. Second, the local farmers were divided into two-way distance increments of 0-50 miles (0-80 km), 51-100 (82-161 km), and more than 100 miles $(161 \mathrm{~km})$ from the local markets. The distributions of local farmers with lower $\mathrm{g} / \mathrm{cwt}$ estimates than from the Florida, Texas, and California shipping points were compared across increments.

\section{Effects of Key Factors on Fuel Use Efficiency}

Surveyed farmers were asked to provide additional information about farm size, farming practices, and weekly marketing activities, as these factors were hypothesized to have a relationship with local farmer transportation $\mathrm{g} / \mathrm{cwt}$. Local farmer $\mathrm{g} / \mathrm{cwt}$ varies according to the farmer's travel distance to market, vehicle MPG, and truckload weight. Although travel distance to a farmers market is exogenously determined for a given farmer, vehicle MPG and truckload weight are transportation efficiency factors under the farmer's control. In the case of truckload weight, variables related to scale, such as farm and vehicle sizes, are expected to affect the amount of produce a farmer delivers to the farmers market. Using the survey data on local farmers' transportation methods in delivering their produce to Knox County farmers markets, an ordinary least squares (OLS) regression model tested hypotheses about how farm and vehicle sizes affect truckload weight. All else equal, farmers hauling heavier truckloads have improved transportation fuel use efficiencies. ${ }^{2}$ The OLS

establishing contractual relationships with local hotels, restaurants, and institutions, such as hospitals and schools, so that deliveries can be made on a consistent basis using larger vehicles (Day-Farnsworth et al., 2009; Diamond \& Barham, 2012; Gunter, Thilmany, \& Sullins, 2012; Northeast Organic Farming Association of Vermont [NOFA-VT] \& Wilson, 2012). However, not all farmers are interested in collective product aggregation. In such cases, local producers may need to increase their own production and distribution scales to 
regression was:

$$
\begin{aligned}
& \text { truckeload }_{i}=\beta_{0}+\beta_{1} \text { acres }_{i}+\beta_{2} \text { organic }_{i}+\beta_{3} \text { acresorg }_{i}+\beta_{4} \text { boxtruck }_{i} \\
& +\beta_{5} \text { mk.tchannels }_{i}+e_{i},
\end{aligned}
$$

where subscript $i$ represents the $i^{\text {th }}$ local farmer $(i=1 \ldots 29)$, truckload is truckload weight per trip to market of mixed fruits and vegetables (lbs.), acres is acres planted in fruits and vegetables for sale at the local farmers market, organic equals 1 if the farmer used certified organic or naturally grown farming methods and 0 otherwise, acresorg is the interaction between acres and organic (acres $\times$ organic), boxtruck equals 1 if the farmer used a box truck ${ }^{3}$ to transport produce to market and 0 otherwise, mktchannels is the number of marketing activities the farmer participated in per week (i.e., multiple farmers markets $(\geq 2)$, CSA shares, farm stands, restaurants, wholesale, and pick-your-own), $\beta_{j}$ $(j=0 \ldots 5)$ are the parameters to be estimated, and $e_{i}$ is the error term assumed to be independently and identically distributed (i.i.d.) with a mean of zero and constant variance. Descriptive statistics of the variables included in the regression are provided in Table 2.

The farm size variable, acres, is a scale variable describing production size and is hypothesized to have a positive effect $\left(\beta_{1}>0\right)$ on the truckload weight of produce delivered to market. The binary variable, organic, controls for production practices and indicates whether a farmer used organic or natural farming methods instead of conventional methods, such as synthetic fertilizers and nonorganically certified insecticides and pesticides. Organic or natural farming is hypothesized to have a negative effect $\left(\beta_{2}<0\right)$ on truckload weight compared to conventional farming because conventional farms tend to be more productive per area of land than organic farms (Seufert, Ramankutty, \& Foley, 2012).

The interaction term, acresorg, takes into account the difference in the effect that increases in farm size may have on conventional and organic

improve transportation fuel use efficiency. Furthermore, for local foods to become more than a niche marketing strategy, local food distribution systems may need to be efficient across all types of market channels: farmers markets, CSA shares, wholesale to hotels, restaurants, and institutions, etc. farmers' truckload weights. The sign of the coefficient of this variable is expected to be negative $\left(\beta_{3}<0\right)$. An additional acre of produce planted by local organic producers is expected to increase truckload weight by a smaller amount than for local producers using conventional farming practices, as synthetic herbicides, pesticides, and fungicides allow conventional farmers to increase their farm size more effectively relative to organic farms that rely on more labor-intensive farming techniques. The binary variable, boxtruck, measures the effect on farmers' truckload weights when the farmer uses a box truck to transport fruits and vegetables to market. This variable models how scaling up vehicle size affects truckload weight. The variable boxtruck is expected to positively $\left(\beta_{4}>0\right)$ affect truckload weight per trip because the farmer's vehicle carrying capacity increases with a larger vehicle.

The final variable, mktchannels, accounts for the number of marketing channels used per week. Farmers with local food sales tend to use more than one marketing channel for fresh produce (Lawless, Stevenson, Hendrickson, \& Cropp, 1999; LeRoux, Schmit, Roth, \& Streeter, 2010; Uva, 2002). These farmers may have larger farms, and thus have greater quantities of produce for sale at the farmers market. If a given farm has several marketing channels, it may use farmers markets as a way to promote its other marketing activities, such as pick-your-own produce or wholesale to restaurants, and therefore brings an ample quantity of produce as a display of on-farm productivity and variety. On the other hand, holding farm size constant, more marketing channels implies less produce per marketing channel, and hence lower truckload weights per trip. In these cases, the farmer may bring less produce to the farmers market. Thus, the effect of mktchannels on truckload weight could be positive, zero, or negative $\left(\beta_{5}>=<0\right)$.

\footnotetext{
${ }^{3}$ Relative to pickup trucks, box trucks have a closed, squareshaped cargo space similar in design to a downsized semitruck shipping container and provide local producers with added hauling capacity.
} 
Table 3. Truckload and MPG by Farm Size and Vehicle Type Assumed in the Sensitivity Analysis

\begin{tabular}{ccccccc}
\hline Scenario & $\begin{array}{c}\text { Number of Acres } \\
(\text { acres/ha) }\end{array}$ & Farming Method & Vehicle Type & $\begin{array}{c}\text { Drivetrain* } \\
\text { and Fuel }\end{array}$ & $\begin{array}{c}\text { Truckload } \\
(\mathrm{lbs} . / \mathrm{kg})\end{array}$ & $\begin{array}{c}\text { Average (MPG/L per } \\
100 \text { km) }\end{array}$ \\
\hline 1 & $2.25 / 0.91$ & Conventional & Pickup & 2-WD, Gas & $443 / 201$ & $18.6 / 12.6$ \\
\hline 2 & $6 / 2.4$ & Conventional & Box Truck & 2-WD, Gas & $1,501 / 681$ & $10.7 / 22.0$ \\
\hline
\end{tabular}

* 2-WD $=$ Two-wheel drive

\section{Locational Advantage Sensitivity Analysis}

Using the truckload regression coefficients and average MPG estimates of the surveyed farmers' vehicles, we conducted sensitivity analysis scenarios to observe how variations in key transportation efficiency factors affect local farmers' locational advantage in the delivery of fruits and vegetables to market. The sensitivity analyses varied farm size and vehicle type (production and distribution scale variables, respectively) to show how travel distance thresholds change when the scales of these variables change in the truckload weight regression.

The assumptions of the sensitivity scenarios are reported in Table

3. Because nearly $70 \%$ of the surveyed farmers used conventional farming methods in production, both scenarios assumed conventional farming practices. Additionally, to simplify the scenario analyses, mktchannels was set at the average of two marketing channels. Two-wheel drive (2-WD) vehicles using gas were assumed in all scenarios, because these were the drivetrain and fuel type observed most frequently in both vehicle type categories (pickup and box truck). Farm size (acreage) was
Figure 2. Local vs. Conventional Transportation Fuel-Use Efficiency

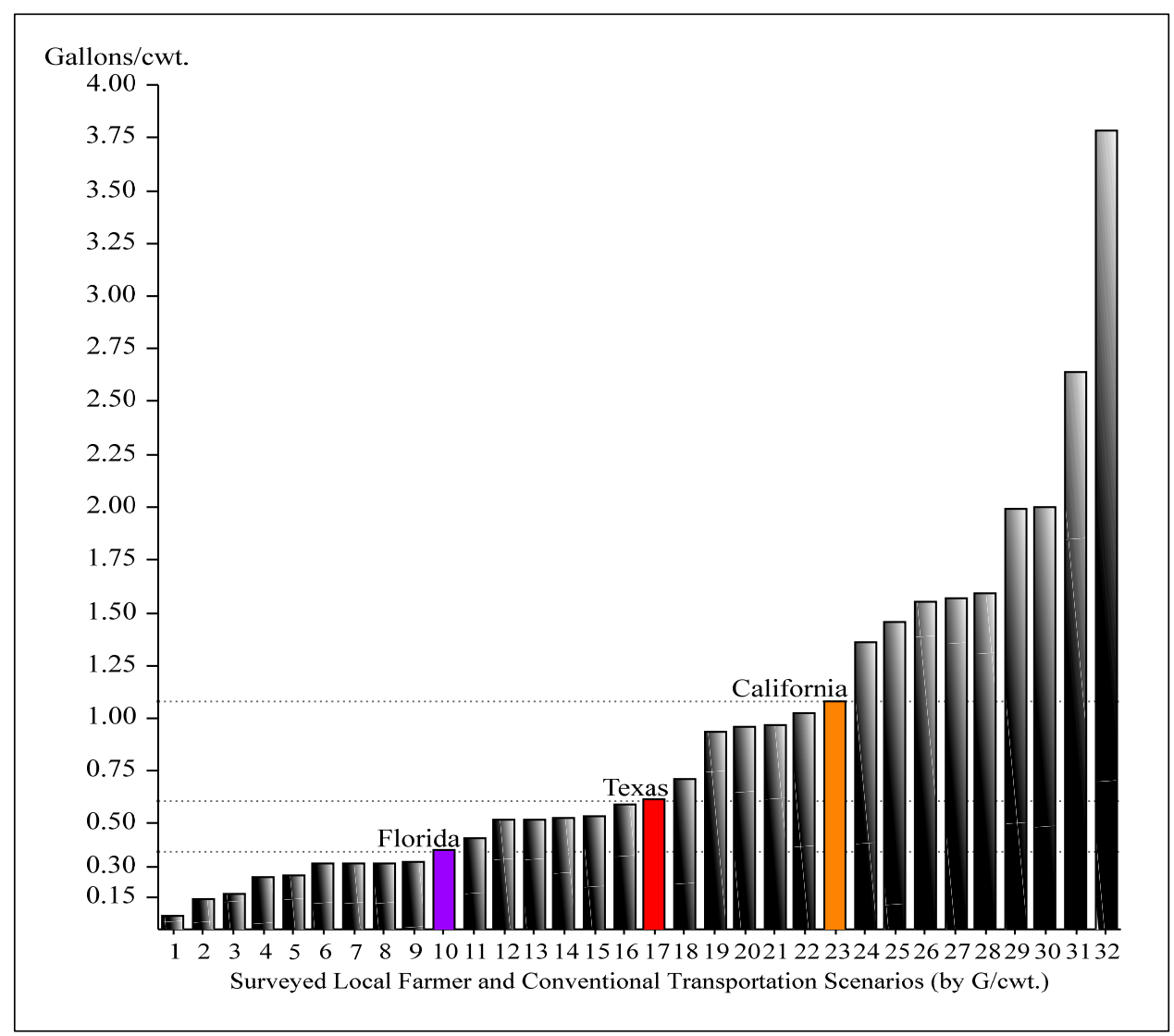


conventional farming methods and delivering produce to market in a box truck with an average fuel efficiency of 10.7 MPG (22.0 L/100 km). Scenario 2 increases the production scale to 6 acres $(2.4 \mathrm{ha})$, corresponding to the average acreage planted in fruits and vegetables by farmers using conventional farming methods and delivering produce to market in a box truck. The maximum travel distance thresholds to the downtown farmers market were geographically graphed for each sensitivity scenario.

\section{Results}

\section{Comparing Local and Conventional Transportation Fuel Use Efficiencies}

Figure 2 shows the estimated $\mathrm{g} / \mathrm{cwt}$ for each farmer compared with the conventional transportation supply chains from Florida, Texas, and California. Approximately $31 \%$ of the interviewed farmers ( 9 farmers) have $\mathrm{g} / \mathrm{cwt}$ below all three conventional transportation shipping points (more efficient than Florida), $52 \%$ of the surveyed farmers (15 farmers) have $\mathrm{g} / \mathrm{cwt}$ less than the Texas and California thresholds (more efficient than Texas), and $69 \%$ have $\mathrm{g} / \mathrm{cwt}$ below the California fuel use threshold (more efficient than California). Nine local farmers have $\mathrm{g} / \mathrm{cwt}$ above the California threshold (less efficient than California), indicating that they are less fuel efficient in transporting local produce to market than produce delivered from all three long distance shipping points. Conversely, if local farmer transportation efficiencies are only compared with fruits and vegetables sourced from Florida, $69 \%(100 \%-31 \%=69 \%)$ of local farmers (29-9=20 farmers) are above the fuel-use threshold for produce shipped from that state (less efficient than Florida).

Figure 3 shows that all 12 farmers with travel distances below 50 two-way miles $(80 \mathrm{~km})$ have lower $\mathrm{g} / \mathrm{cwt}$ estimates than the conventional transportation systems from Texas and California, while nine of the 12 farmers transport produce to market at least as efficiently as produce shipped from Florida. These farmers' transportation efficiencies are primarily attributed to minimal travel distances to market and less to heavier truckloads. The median truckload for farmers traveling less than 50 two-way miles $(80 \mathrm{~km})$ to market is 588 lbs. (267 kg), approximately $23 \%$ below the average truckload weight of all surveyed farmers.

Local farmer competitiveness with the three conventional supply chains is mixed for farmers traveling between 50 and 100 two-way miles (82 and $161 \mathrm{~km})$ and over 100 two-way miles $(161 \mathrm{~km})$ to market, respectively. Surveyed farmer $\mathrm{g} / \mathrm{cwt}$ estimates in these travel distance ranges are all above the Florida threshold. Five of the nine
Figure 3. Comparing Local and Conventional Transportation Efficiencies by Travel Distance to Market

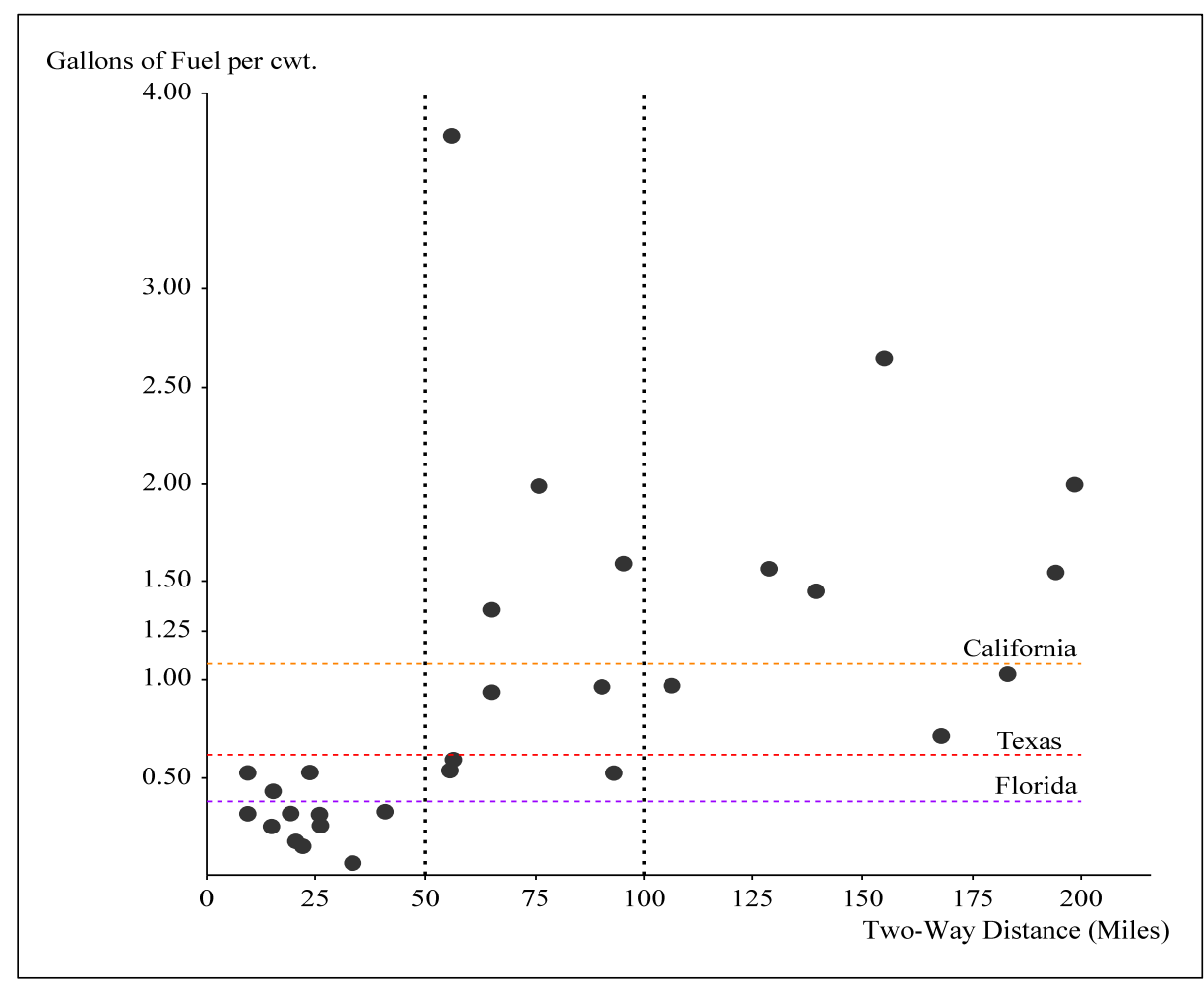


farmers with two-way travel distances between 50 and 100 miles have $\mathrm{g} / \mathrm{cwt}$ estimates below the California threshold, while only three of the eight farmers traveling more than 100 two-way miles have $\mathrm{g} / \mathrm{cwt}$ estimates below the California threshold. These three farmers compensate their longer travel distances with heavier truckload weights.

These findings support King et al. (2010), as the surveyed farmers with the shortest travel distances tend to have lower $\mathrm{g} / \mathrm{cwt}$ than the conventional transportation supply chains. The transportation efficiencies of farmers farther from the farmers market are often not competitive with the three conventional transportation systems because their truckload weights are insufficient to offset the added travel distance to market. Local farmers can improve their transportation efficiencies by increasing truckload weights or employing more fuel-efficient (higher MPG) vehicles. However, improving vehicle MPG usually requires using a smaller vehicle, which in turn may constrain vehicle carrying capacity.

\section{The Impact of Scale: Modeling Truckload} Deliveries to Market

The estimated truckload weight regression is reported in Table 4 . The $R^{2}$ of 0.90 indicates that

\section{Table 4. Results for Truckload Weight (Ibs.) Regression}

\begin{tabular}{lcc}
\hline Variable & Coefficient & $P$-value \\
\hline intercept & $\begin{array}{c}215.56 \\
(112.54)\end{array}$ & 0.07 \\
\hline acres & $\begin{array}{l}128.67 \\
(12.11)\end{array}$ & 0.00 \\
\hline organic & $\begin{array}{c}209.65 \\
(139.48)\end{array}$ & 0.15 \\
\hline acresorg & $\begin{array}{c}-119.65 \\
(24.37)\end{array}$ & 0.00 \\
\hline boxtruck & $\begin{array}{c}574.81 \\
(117.49)\end{array}$ & 0.00 \\
\hline mktchannels & -30.95 & 0.59 \\
\hline$n$ & $(55.96)$ & \\
\hline$R^{2}$ & 29 & 0.00 \\
\hline F-statistic (5,23 df) & 0.90 & 0.91 \\
\hline Breusch-Pagan statistic & 37.01 & \\
(5 df) & 1.48 & \\
\hline
\end{tabular}

the explanatory variables in the model explain $90 \%$ of the variation in truckload weight among the 29 surveyed farmers. The Breusch-Pagan test fails to reject the null hypothesis of no heteroskedasticity (Breusch \& Pagan, 1979). Multicollinearity diagnostics showed no statistical significance of strong linear relationships among the explanatory variables, as all variance inflation factors were below 1.8. Therefore, the regression coefficients in Table 4 are best linear unbiased estimators (Wooldridge, 2012).

Although the coefficient for organic is significant only at the $15 \%$ level, a joint test of the null hypothesis that organic and acresorg are jointly zero was rejected $(F=13.8 ; 2,23 d f$; Critical $F=5.66$ $[\alpha=0.01])$ (Wooldridge, 2012). Thus, truckload weights are different for organic and conventional farms of the same size. Furthermore, analysis of the production scale variable, acres, and the interaction term, acresorg, suggests a nontrivial difference in the effect of an additional acre on truckload weights between conventional and organic fruit and vegetable farmers. Controlling for vehicle type and marketing channels, an additional acre for a conventional farmer (organic $=0$ ) yields 129 lbs. (59 $\mathrm{kg}$ ) more produce shipped to market per truckload, on average. Although organic farmers (organic $=1$ ) ship on average $210 \mathrm{lbs}$. (95 kg) more produce per truckload to local markets than conventional farmers, the effect of an additional acre on truckload weight is only $9 \mathrm{lbs}$. (128.67 lbs. $-119.65 \mathrm{lbs} .=9.02$ lbs.), 120 lbs. less than the effect on truckload weight of an additional acre for conventional farmers.

Because the coefficient of acresorg is negative, the difference between the average truckload weights of the two farming methods diminishes as the number of acres planted in fruits and vegetables increases. The regression results show that organic farmers producing less than 1.75 acres (0.71 ha) (209.65 lbs. -119.65 lbs. $\times 1.75$ acres $\approx 0$ lbs.) of fruits and vegetables deliver larger truckloads to the farmers market than conventional farmers with the same farm size. However, as acreage increases beyond 1.75 acres, conventional farmers ship heavier truckloads than organic farmers, for the same farm size. This result suggests diminishing returns to farm scale for 
Table 5. Sensitivity Analysis Results for One-Way and Two-Way Break-Even Travel Distance Thresholds

\begin{tabular}{|c|c|c|c|c|c|c|}
\hline \multirow[b]{3}{*}{ Scenario } & \multicolumn{6}{|c|}{$\begin{array}{l}\text { Conventional Shipping Points } \\
\text { Break-Even Mileage/Kilometer Marker }\end{array}$} \\
\hline & \multicolumn{2}{|c|}{$\begin{array}{c}\text { Florida } \\
(\mathrm{g} / \mathrm{cwt}=0.38)\end{array}$} & \multicolumn{2}{|c|}{$\begin{array}{c}\text { Texas } \\
(\mathrm{g} / \mathrm{cwt}=0.62)\end{array}$} & \multicolumn{2}{|c|}{$\begin{array}{c}\text { California } \\
(\mathrm{g} / \mathrm{cwt}=1.08)\end{array}$} \\
\hline & One-Way & Two-Way & One-Way & Two-Way & One-Way & Two-Way \\
\hline 1 & $15.5 / 24.9$ & $31 / 50$ & $25.5 / 41$ & $51 / 82$ & 44 / 71 & $88 / 142$ \\
\hline 2 & $30 / 48$ & $60 / 97$ & $49.5 / 79.7$ & $99 / 159$ & $86 / 138$ & $172 / 277$ \\
\hline
\end{tabular}

Note: Scenario assumptions are reported in Table 3.

organic farmers relative to conventional farmers. A $t$-test was used to test the null hypothesis that $\beta_{2} / \beta_{3}=0$. The point estimate of 1.75 (209.65/ $119.65)$ derived from the coefficients of acres and acresorg is significantly different from zero at the 10\% level $(t=1.77 ; 23 d f, P$-value $=.09)$ (Gregory \& Veall, 1985; Wooldridge, 2010). The result suggests that local conventional farmers of fruits and vegetables may have increasing production advantages over organic growers as farm size increases.

The binary indicator variable, boxtruck, is significant at the $1 \%$ level, indicating that vehicle type is an important factor in determining truckload weight. Controlling for all other variables, a farmer using a box truck carries, on average, 575 lbs. (261 $\mathrm{kg}$ ) more produce to market than a farmer using a pickup truck for transportation. Thus, to improve the Knoxville area's local food transportation efficiencies, scaling up vehicle sizes to allow for heavier truckload shipments per trip may have a considerable impact. To illustrate using the regression coefficients, a local farmer who produces 4 acres (1.6 hectares) in fruits and vegetables, employs conventional agricultural techniques, uses two alternative marketing channels, and transports produce to the farmers market in a pickup truck is estimated to ship $668 \mathrm{lbs}$. (303 kg) of produce per trip to market. If this same farmer were to use a box truck, truckload weight would nearly double to 1,243 lbs. (564 kg), which leads to greater transportation fuel use efficiency per trip to market.

However, using a box truck alone does not necessarily enable a farm to transport larger loads to market. The production scale must also be adequately large to take advantage of the added carrying capacity. The average number of acres of fruit and vegetable production for the 9 farmers using a box truck was 6.25 acres $(2.53 \mathrm{ha})$, whereas the remaining 20 local producers with pickup trucks planted an average of 2.75 acres $(1.11 \mathrm{ha})$.

The regression model provides a quantifiable example of the potential impact on local farmer transportation efficiencies by scaling up local food production. While some authors (Day-Farnsworth et al., 2009; Diamond \& Barham, 2012) refer to the significance of scaling up the local food supply chain via farmer cooperatives and food hubs, in this study the impact of increasing production and distribution scale is analyzed on the microsetting for a single farm. The two scale variables, acres and boxtruck, which account for the influence of production and distribution scales on farmer truckload weights, are both significant and their coefficients are nontrivial in magnitude.

\section{Sensitivity Analysis Results}

The one-way and two-way travel distance thresholds are presented in Table 5. Delivering fresh produce from Florida, Texas, and California to Knoxville requires $0.38 \mathrm{~g} / \mathrm{cwt}, 0.62 \mathrm{~g} / \mathrm{cwt}$, and $1.08 \mathrm{~g} / \mathrm{cwt}$, respectively. The two-way travel distance thresholds are determined where the local farmer travel distance functions intersect the $\mathrm{g} / \mathrm{cwt}$ from the conventional shipping points and depend on the farmer's production and vehicle characteristics in Table 3. Results from the sensitivity analysis show that by scaling up production and transportation operations, local farmer transportation fuel use efficiency is improved, and in turn the competitive travel distance thresholds are extended. However, the sensitivity analysis does not account for changes in farmer welfare or alterations in the final price paid by consumers for locally grown fruits and vegetables as local farmers 
increase their transportation efficiencies.

Figures 4 and 5 provide a geographical mapping of the one-way travel distance thresholds of the sensitivity scenarios. The three colored areas represent competitive transportation zones within which local farmers can ship their produce to market and have a locational advantage in transportation over at least one of the three long distance conventional supply chains. The sizes of the competitive transportation zones are based on the farmers' transportation efficiencies, which are determined by the truckload weights and vehicle MPG estimates presented in Table 3. The maps illustrate that if local farmers' production and distribution scales are not sufficiently large, the geographical scope of their locational advantage in transportation is significantly reduced.

Figure 4 shows that the small-scale, pickup truck farming operation modeled in scenario 1 must be located roughly one county away from the downtown market to compete with the transportation efficiency of produce shipped from California. The scenario 1 farmer's transportation fuel use efficiency can compete with Florida produce only if the farm is located in Knox County, within 15.5 miles $(24.9 \mathrm{~km})$ of the downtown market. Small, pickup truck farms, therefore, need highly localized marketing strategies to achieve comparable transportation efficiencies with conventional food distribution networks.

Production and distribution scales increase in scenario 2 , and in turn the local farmer delivers larger truckloads of fresh produce to market. Larger production and distribution scales allow the modeled farmer to significantly expand the geographical range across which fresh produce can be delivered to the downtown market without exceeding the conventional travel distance

\section{Figure 4. Scenario 1 Competitive Transportation Zones}

Scenario 1 models the average local farmer with 2.25 acres (0.91 ha) planted in fruits and vegetables and a pickup truck for transportation (see Table 3 for scenario assumptions).

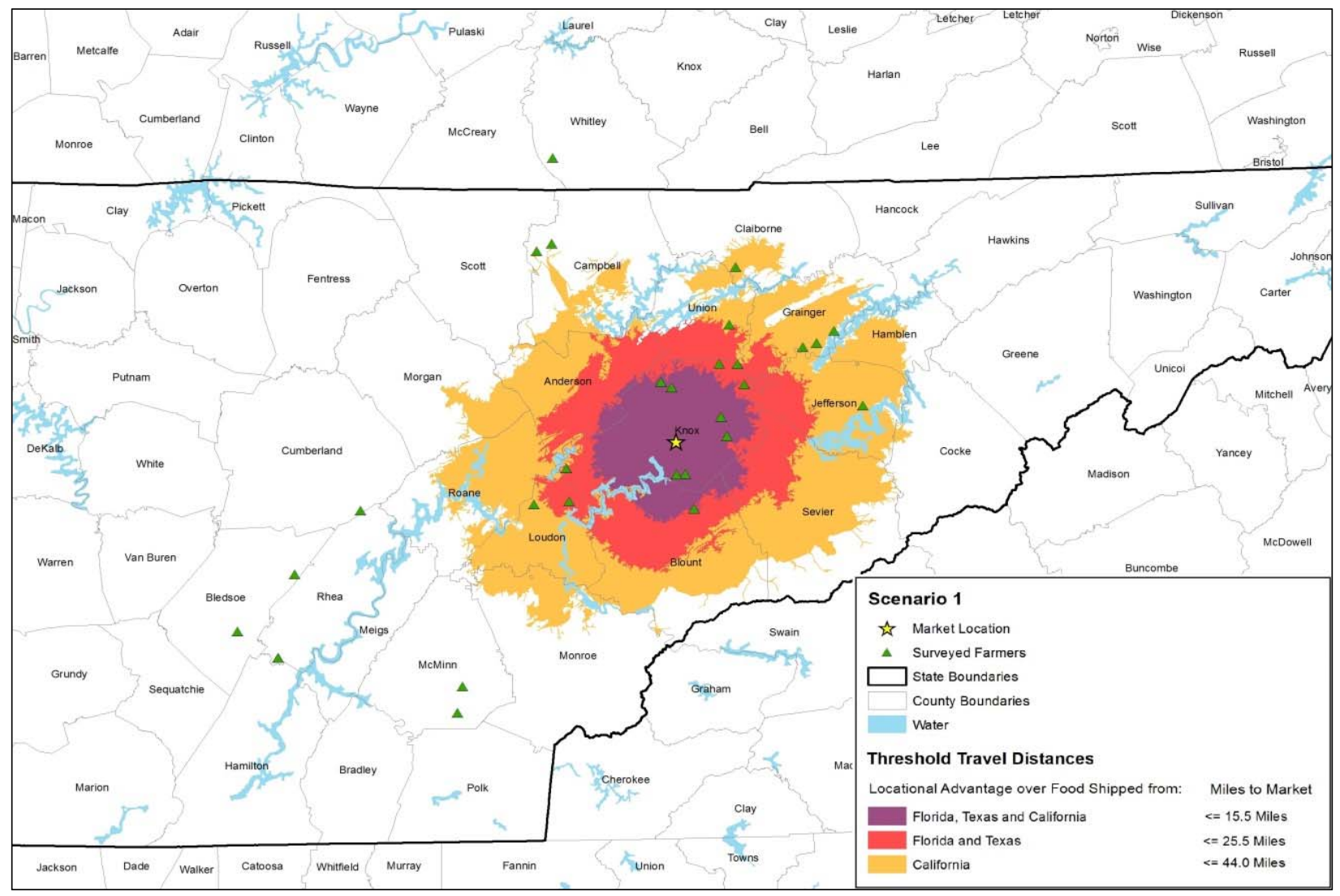


thresholds (Figure 5). Farms hauling more weight (i.e., 1,000-1,500 lbs. or 454-680 kg) can deliver produce to the downtown market from within two or three counties and maintain their locational advantage over conventional food supply chains in terms of transportation fuel use per unit of produce shipped. Farmers who are scaled up in production and distribution have the opportunity to market fruits and vegetables in a more "regional" sense by traveling up to 86 one-way miles $(138 \mathrm{~km})$ to market before surpassing the travel distance threshold for California produce.

\section{Policy Implications and Conclusions}

U.S. fruit and vegetable production has become increasingly concentrated in states such as California, Texas, and Florida due to their geographical and climatological comparative advantages in production (Lucier et al., 2006; Paggi et al., 2012;
USDA NASS, 2014). Large-scale, specialized production is conveniently wedded with an efficient transportation network characterized by economies of scale. While large-scale fruit and vegetable production and transportation largely contribute to the low-cost conventional food supply chain, our study shows that factors of location and scale also play key roles in determining Knoxville-area local farmers' transportation efficiencies. Although the higher prices received for their differentiated products may enable local farmers to be profitable regardless of how their transportation fuel use efficiencies compare with the conventional food supply chain, if local foods are to become more than a niche market, improving transportation efficiency by scaling up local farmer production and distribution may be a desirable goal for local farmers, consumers, and food policy-makers.

In the case of Knoxville, our study showed

\section{Figure 5. Scenario 2 Competitive Transportation Zones}

Scenario 2 models the average, scaled-up local farmer who plants 6 acres (2.4 ha) in fruits and vegetables and employs a box truck for transportation (see Table 3 for scenario assumptions).

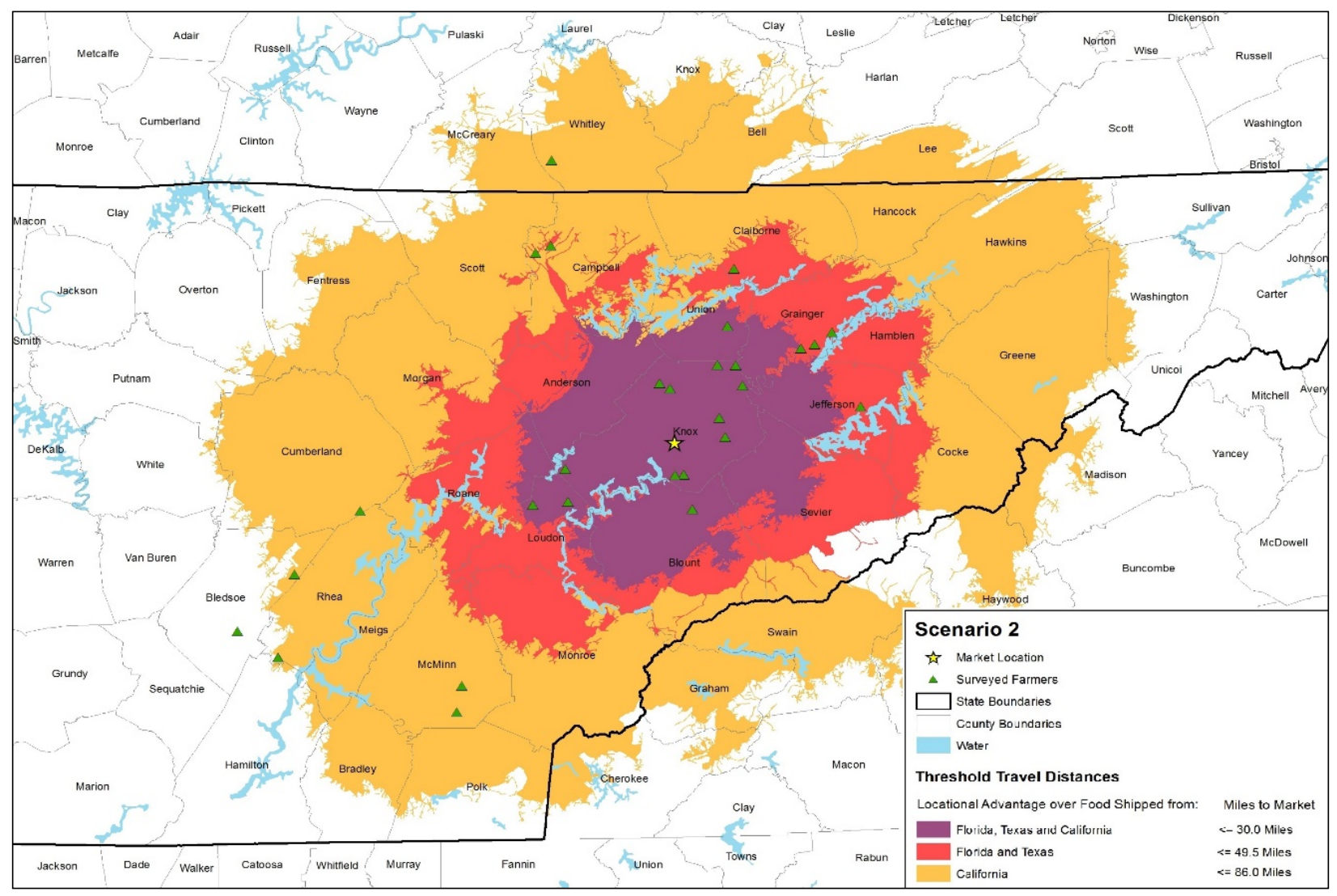


that despite their relatively small truckloads, all 12 farms operating within 25 miles of the downtown market (50 two-way travel miles, or $80 \mathrm{~km}$ ) delivered their produce to market at least as efficiently as conventionally distributed foods from California. Local farmers traveling further than 25 oneway miles $(40 \mathrm{~km})$ were less competitive with the three conventional transportation scenarios unless these more distant farms had adequately scaled up their production and distribution of fresh produce. Because the farms within the 25-mile competitive transportation zone cannot satisfy Knoxville's local food supply needs with their small-scale operations, policies designed to meet the city's objectives by conserving farmland beyond the 25 -mile threshold need to ensure that the production and transportation scales of more distant farming operations are sufficiently large so that their transportation fuel use efficiencies are competitive with conventional food distribution systems.

The OLS regression results suggest that farm size (acreage) and vehicle type (pickup or box truck) have a significant effect on the amount of fresh produce delivered to market per trip. Using the scale coefficients from the OLS regression (acres and boxtruck), the transportation sensitivity analysis illustrates that as the surveyed local farmers increased their distribution scales, they delivered produce to market more efficiently, and in turn extended their competitive transportation zones outward to compete more favorably with conventionally transported foods, as predicted by Hotelling's spatial competition model (1929). ${ }^{4}$ Our model showed that small-scale, pickup truck farmers could be located up to 44 miles $(71 \mathrm{~km})$ from the downtown market before losing their locational advantage in transportation to produce shipped from California. A larger-scale farm employing a box truck for transportation could travel nearly double the distance (86 miles or 138 $\mathrm{km}$ ) before it surpassed the California threshold. As travel distance to market increases, balancing

\footnotetext{
${ }^{4}$ Hotelling's spatial competition model (1929) suggests that increasing local farmers' production and distribution efficiencies will expand their competitive market area by lowering locally produced food prices relative to conventionally produced foods. This study, however, only
}

out the added travel miles with larger truckloads becomes essential if local farmers are to compete with the transportation fuel use efficiency of conventional supply chains.

These findings corroborate the results of other local food transportation studies (King et al., 2010; Mundler \& Rumpus, 2012; Pirog et al., 2001; Wallgren, 2006). While most research has documented the effects of scaling up local food production and distribution with qualitative analyses (Bittner et al., 2011; Day-Farnsworth \& Miller, 2014; Day-Farnsworth et al., 2009), these regression and sensitivity results offer local food analysts a quantitative baseline for the impacts of scaling up local food networks. However, because the sample is not random, the regression results cannot be used to make inferences about the broader population of farmers transporting food to local markets. The model only pertains to the 29 surveyed Knoxville-area farmers.

Determining the competitive transportation zones in other cities could be useful information to help policy-makers and urban planners develop more efficient farm conservation and infrastructure programs in support of local food systems. The transportation fuel use efficiency thresholds will be unique to every community, as they are contingent on the shipping points of their conventional food suppliers and local farmers' locations, and production and distribution scales. The local food economy in Knoxville is characterized primarily by numerous small- and midsized farms that individually market their fresh produce at farmers markets and through CSA shares. The city has not developed a local food aggregation network through food hubs or farmer cooperatives. Thus, comparing local farmers' respective transportation fuel use efficiencies with the conventional food supply chain, and developing competitive transportation zones for these local producers, were appropriate for the Knoxville-area food system. However, our methods could also be applied in

analyzes the transportation efficiency component of local farmers' operations. Investigating the extent to which local food prices change as a result of local farmers increasing their production and distribution scales could be addressed with future research. 
food systems where local food aggregation operations are delivering fresh produce to larger wholesale buyers, such as hotels, restaurants, and institutions.

Glaeser \& Kohlhase (2004) identify falling transportation costs related to technological innovation as a factor that has transformed the structure of the modern economy. Without the relatively low transportation costs and technological advances that facilitate long distance food distribution, concentrating the production of perishable food items in regions remote from most consumer markets may become less viable. If transportation costs were to increase significantly, local farmers with a locational advantage in transportation could have greater marketing opportunities, as wholesalers and retailers facing higher distribution costs may alter their procurement strategies by adopting regional sourcing strategies (Acharya, Kagan, \& Manfredo 2009; Gosier, Simchi-Levi, Wright, \& Bentz, 2008). In determining the competitive transportation zones in other local food systems, some communities may find that most of their local farmers transport their produce to market less efficiently than food shipped conventionally, and thus are outside of the competitive travel distance thresholds. Indeed, some local food economies may be more vulnerable to fuel price increases than their long distance conventional competition. Conversely, our study indicates that food systems in which a large proportion of the local farmers are located near the urban core are more sustainable and resilient to fuel price shocks, as their shorter travel distances may give the closest farming operations a distinct locational advantage in transportation over the long distance conventional transportation system.

\section{Acknowledgements}

Special thanks to Dayton Lambert, Edward Yu, Roland Roberts, and Brad Wilson at the University of Tennessee's Department of Agricultural \& Resource Economics for their helpful commentary and technical support during the development of this research. Also, we thank the local farmers in east Tennessee who participated in our survey, as without their willingness to collaborate our investigation would not be possible.

\section{References}

Acharya, R. N., Kagan, A., \& Manfredo, M. R. (2009). Impact of rising fuel cost on perishable product procurement. Journal of Business Logistics, 30(1), 223 242. http://dx.doi.org/10.1002/j.21581592.2009.tb00106.x

Ashby, B. H. (1995). Protecting perishable foods during transport by truck. Washington, D.C.: USDA Agricultural Marketing Service. http://dx.doi.org/10.9752/TS024.07-2006

Avetisyan, M., Hertel, T., \& Sampson, G. (2014). Is local food more environmentally friendly? The GHG emissions impacts of consuming imported versus domestically produced food. Environmental and Resource Economics, 58(3), 415-462. http://dx.doi.org/10.1007/s10640-013-9706-3

Bittner, J., Day-Farnsworth, L., Miller, M., Kozub, R., \& Gollnik, B. (2011). Maximizing freight movements in local food markets (Report No. CFIRE 04-23). Madison, Wisconsin: National Center for Freight and Infrastructure Research and Education (CFIRE), University of Wisconsin-Madison. Retrieved from http://www.wistrans.org/cfire/ research/projects/04-23/

Breusch, T. S., \& Pagan, A. R. (1979). A simple test for heteroscedasticity and random coefficient variation. Econometrica, 47(5), 1287-1294. http://dx.doi.org/10.2307/1911963

Casavant, K., Denicoff, M., Jessup, E., Taylor, A., Nibarger, D., Sears, D.,... Olowolayemo, S. (2010). Study of rural transportation issues. Washington, D.C.: USDA, Agricultural Marketing Service. http://dx.doi.org/10.9752/TS041.04-2010

Chandler, A. D., \& Hikino, T. (2009). Scale and scope: The dynamics of industrial capitalism. Cambridge, Massachusetts: Harvard University Press.

Coley, D., Howard, M., \& Winter, M. (2009). Local food, food miles and carbon emissions: A comparison of farm shop and mass distribution approaches. Food Policy, 34(2), 150-155. http://dx.doi.org/10.1016/i.foodpol.2008.11.001

Coyle, W., Hall, W., \& Ballenger, N. (2001). Transportation technology and the rising share of U.S. perishable food trade (Report No. WRS 0101). In A. Regmi (Ed.), Changing Structure of Global Food Consumption and Trade (pp. 31-40). Washington, D.C.: USDA, Economic Research Service. Retrieved from http://www.ers.usda.gov/media/ 293601/wrs011f_1_.pdf 
Day-Farnsworth, L., McCown, B., Miller, M., \& Pfeiffer, A. (2009). Scaling up: Meeting the demand for local food. Madison: University of Wisconsin Cooperative Extension Agricultural Innovation Center and University of Wisconsin-Madison Center for Integrated Agricultural Systems. Retrieved from http://www.cias.wisc.edu/scaling-up-meeting-thedemand-for-local-food/

Day-Farnsworth, L., \& Miller, M. (2014). Networking across the supply chain: Transportation innovations in local and regional food systems. Madison: University of Wisconsin-Madison Center for Integrated Agricultural Systems. http://dx.doi.org/10.9752/TS202.06-2014

Diamond, A., \& Barham, J. (2012). Moving food along the value chain: Innovations in regional food distribution. Washington, D.C.: USDA, Agricultural Marketing Service. http://dx.doi.org/10.9752/MS045.03-2012

Eiselt, H. A., \& Laporte, G. (1989). Competitive spatial models. European Journal of Operational Research, 39(3), 231-242. http://dx.doi.org/10.1016/03772217(89)90161-6

Etemadnia, H., Goetz, S. J., Canning, P., \& Tavallali, M. S. (2015). Optimal wholesale facilities location within the fruit and vegetables supply chain with bimodal transportation options: An LP-MIP heuristic approach. European Journal of Operational Research, 244(2), 648-661. http://dx.doi.org/10.1016/j.ejor.2015.01.044

Friedlaender, A. F., \& Spady, R. H. (1980). A derived demand function for freight transportation. The Review of Economics and Statistics, 62(3), 432-441. http://dx.doi.org/10.2307/1927111

Fujita, M. (2010). The evolution of spatial economics: From Thünen to the New Economic Geography. Japanese Economic Review, 61(1), 1-32. http://dx.doi. org/10.1111/j.1468-5876.2009.00504.x

Glaeser, E. L., \& Kohlhase, J. E. (2004). Cities, regions and the decline of transport costs. Papers in Regional Science, 83(1), 197-228. http://dx.doi.org/10.1007/s10110-003-0183-x

Google Maps. (2014). Google. Accessed at https://maps.google.com

Gosier, R., Simchi-Levi, D., Wright, J., \& Bentz, B. A. (2008). Past the tipping point: Record oil prices require new supply chain strategies to enable future high performance.
Retrieved from http://www.criticaleye.com/ insights-servfile.cfm? $\mathrm{id}=650 \mathrm{\& view}=1$

Gregory, A. W., \& Veall, M. R. (1985). Formulating

Wald tests of nonlinear restrictions. Econometrica, 53(6), 1465-1468. http://dx.doi.org/10.2307/1913221

Gunter, A., Thilmany, D., \& Sullins, M. (2012). What is the new version of scale efficient: A values-based supply chain approach. Journal of Food Distribution Research, 43(1), 24-31. Retrieved from http://purl.umn.edu/139447

Heller, M. C., \& Keoleian, G. A. (2003). Assessing the sustainability of the US food system: A life-cycle perspective. Agricultural Systems, 76(3), 1007-1041. http://dx.doi.org/10.1016/S0308-521X(02)00027$\underline{6}$

Hendrickson, J. (1994). Energy use in the U.S. food system: A summary of existing research and analysis. Madison: University of Wisconsin-Madison Center for Integrated Agricultural Systems. Retrieved from http://www.cias.wisc.edu/energy-use-in-the-usfood-system-a-summary-of-existing-research-andanalysis/

Hotelling, H. (1929). Stability in competition. The Economic Journal, 39(153), 41-57. http://dx.doi.org/10.2307/2224214

Huang, S. (2004). Global trade patterns in fruits and vegetables (Report No. WRS-04-06). Washington, D.C.: USDA, Economic Research Service. http://dx.doi.org/10.2139/ssrn.753525

Hummels, D. (2007). Transportation costs and international trade in the second era of globalization. The Journal of Economic Perspectives, 21(3), 131-154. http://dx.doi.org/10.1257/jep.21.3.131

Isard, W., \& Peck, M. J. (1954). Location theory and international and interregional trade theory. The Quarterly Journal of Economics, 68(1), 97-114. http://dx.doi.org/10.2307/1881920

Jones, A. (2002). An environmental assessment of food supply chains: A case study on dessert apples. Environmental Management, 30(4), 560-576. http://dx.doi.org/10.1007/s00267-002-2383-6

Kaplin, L. (2012). Energy (in)efficiency of the local food movement: Food for thought. Fordham Envtironmental Law Review, 23, 139-161. Retrieved from https://works.bepress.com/lauren kaplin/2/ 
Kaufman, P. R., Handy, C. R., McLaughlin, E. W., Park, K., \& Green, G. M. (2000). Understanding the dynamics of produce markets: Consumption and consolidation grow (Agriculture Information Bulletin No. 758). Retrieved from http://www.ers.usda.gov/ publications/aib-agricultural-informationbulletin/aib758.aspx

King, R. P., Gómez, M. I., \& DiGiacomo, G. (2010). Can local food go mainstream? Choices, 25(1), 1-5. http://purl.umn.edu/93824

King, R. P., Hand, M. S., \& DiGiacomo, G. (2013). Research design for local food case studies. In R. P. King, M. S. Hand, \& M. I. Gómez (Eds.), Growing local: Case studies on local food supply chains (pp. 14-32). Lincoln and London: University of Nebraska Press.

King, R. P., Hand, M. S., DiGiacomo, G., Clancy, K., Gómez, M. I., Hardesty, S.D.,...McLaughlin, E.W. (2010). Comparing the structure, size, and performance of local and mainstream food supply chains (Economic Research Report No. ERR-99). Washington, D.C.: USDA, Economic Research Service. Retrieved from http://www.ers.usda.gov/publications/erreconomic-research-report/err99.aspx

Launhardt, W. (1885). Mathematische begründung der volkswirtschaftslehre [Mathematical Principles of Economics]. Leipzig, Germany: W. Engelmann.

Lawless, G., Stevenson, G. W., Hendrickson, J., \& Cropp, R. (1999). The farmer-food buyer dialogue project (UWCC Occasional Paper No. 13). Madison: University of Wisconsin-Madison Center for Cooperatives. Retrieved from http://www.uwcc.wisc.edu/info/ffbuyer/toc.html

LeRoux, M. N., Schmit, T. M., Roth, M., \& Streeter, D. H. (2010). Evaluating marketing channel options for small-scale fruit and vegetable producers. Renewable Agriculture and Food Systems, 25(01), 16-23. http://dx.doi.org/10.1017/S1742170509990275

Low, S. A., \& Vogel., S. J. (2011). Direct and intermediated marketing of local foods in the United States (Economic Research Report No. ERR-128). Washington, D.C.: USDA, Economic Research Service. http://dx.doi.org/10.2139/ssrn.2114361

Lucier, G., Pollack, S., Ali, M., \& Perez, A. (2006). Fruit and vegetable backgrounder (Outlook No. VGS-31301).Washington, D.C.: USDA, Economic Research Service. Retrieved from http://www.ers.usda.gov/ publications/vgs-vegetables-and-pulses-outlook/ vgs-31301.aspx
Mariola, M. J. (2008). The local industrial complex? Questioning the link between local foods and energy use. Agriculture and Human V alues, 25(2), 193-196. http://dx.doi.org/10.1007/s10460-0089115-3

Marshall, A. (1920). Principles of economics ( $8^{\text {th }}$ ed.). London: Macmillan.

Martinez, S., Hand, M. S., Da Pra, M., Pollack, S., Ralston, K., Smith, T.,...Newman, C. (2010). Local food systems: Concepts, impacts, and issues (Economic Research Report No. ERR-97). Washington, D.C.: USDA, Economic Research Service. Retrieved from http://www.ers.usda.gov/publications/erreconomic-research-report/err97.aspx

McCann, P. (2013). Modern urban and regional economics (2nd ed.). Oxford, UK: Oxford University Press.

Moneta, C. (1959). The estimation of transportation costs in international trade. Journal of Political Economy, 67(1), 41-58. http://dx.doi.org/10.1086/258129

Mundler, P., \& Rumpus, L. (2012). The energy efficiency of local food systems: A comparison between different modes of distribution. Food Policy, 37(6), 609-615. http://dx.doi.org/10.1016/i.foodpol.2012.07.006

North, D. C. (1955). Location theory and regional economic growth. The Journal of Political Economy, 63(3), 243-258. Retrieved from http://www.jstor.org/stable/1825076

Northeast Organic Farming Association of Vermont (NOFA-VT) \& Wilson, R. (2012). Scaling up Vermont's local food production, distribution, and marketing. Retrieved from http://nofavt.org/ resources/farm-institution-research-papers-reports

Ohlin, B. (1934). Interregional and international trade. Political Science Quarterly, 49(1), 126-128. http://dx.doi.org/10.2307/2143331

Paggi, M. S., Noel, J. E., Yamazaki, F., Hurley, S., \& McCullough, M. (2012). An analysis of California agricultural transportation origins, destinations, modal competition and industry perspectives: Selected fresh fruits and vegetables. Fresno, California: Fresno State University. Retrieved from http:/ fresnostate.edu/ jcast/cab/presentations/index.html

Palander, T. F. (1935). Beiträge zur standortstheorie [Contributions to location theory]. Uppsala: Almqvist and Wiksells Boktryckeri-A.-B. 
Paxton, A. (1994). The food miles report: The dangers of long distance food transport. London: SAFE Alliance.

Pirog, R., Van Pelt, T., Enshayan, K., \& Cook, E. (2001). Food, fuel, and freeways: An Iowa perspective on how far food travels, fuel usage, and greenhouse gas emissions. Ames: Iowa State University, Leopold Center for Sustainable Agriculture. Retrieved from http://lib.dr.iastate.edu/leopold_pubspapers/3/

Rebitzer, G., Ekvall, T., Frischknecht, R., Hunkeler, D., Norris, G., Rydberg, T.,...Pennington, D. W. (2004). Life-cycle assessment, part 1: Framework, goal and scope definition, inventory analysis, and applications. Environment International, 30(5), 701-720. http://dx.doi.org/10.1016/j.envint.2003.11.005

Saunders, C. M., Barber, A., \& Sorenson, L.-C. (2009, February). Food miles, carbon footprinting and their potential impact on trade. Paper presented at the 2009 Conference of the Australian Agricultural and Resource Economics Society, Cairns, Australia. http://purl.umn.edu/48051

Saunders, C., Barber, A., \& Taylor, G. (2006). Food miles: Comparative energy/emissions performance of $\mathrm{New}$ Zealand's agriculture industry (Report No. 285). Lincoln, Canterbury, New Zealand: Agribusiness and Economics Research Unit, Lincoln University. Retrieved from http://ucanr.edu/datastoreFiles/608-324.pdf

Schlich, E., \& Fleissner, U. (2005). The ecology of scale: Assessment of regional energy turnover and comparison with Glal food. The International Journal of Life Cycle Assessment, 10(3), 219-223. http://dx.doi.org/10.1065/lca2004.09.180.9

Seufert, V., Ramankutty, N., \& Foley, J. A. (2012). Comparing the yields of organic and conventional agriculture. Nature, 485(7397), 229-232. http://dx.doi.org/10.1038/nature11069

Sim, S., Barry, M., Clift, R., \& Cowell, S. J. (2007). The relative importance of transport in determining an appropriate sustainability strategy for food sourcing: A case study of fresh produce supply chains. The International Journal of Life Cycle Assessment, 12(6), 422-431. http://dx.doi.org/10.1065/lca2006.07.259

U.S. Census Bureau. (2010). County business patterns. Washington, D.C.: United States Department of Commerce.

U.S. Department of Agriculture, Agricultural Marketing Service (USDA AMS). (2014a). Fresh fruit and vegetable shipments: By commodities, states, and months. (FVAS-4 calendar year 2013). Retrieved from http://www.ams.usda.gov/sites/default/files/medi a/Annual $\% 20$ Fresh $\% 20$ Fruit $\% 20$ and $\% 20$ Vegetable \%20Shipments $\% 202013$.pdf

USDA AMS. (2014b). Agricultural refrigerated truck quarterly. Retrieved from https://www.ams.usda. gov/services/transportation-analysis/agrtq/archive

USDA, National Agricultural Statistics Service (USDA NASS). (2013). California agricultural statistics 2012 crop year. Retrieved from https://www.nass.usda. gov/Statistics by State/California/Publications/ California Ag Statistics/Reports/

USDA NASS. (2014). 2012 Census of Agriculture highlights: Farm economics (ACH12-2). Washington, D.C.: Author. Retrieved from https://www.agcensus. usda.gov/Publications/2012/Online Resources/ Highlights/Farm Economics/

U.S. Department of Energy. (2014). Find and compare cars [Web tool]. Retrieved from http://www.fueleconomy.gov/feg/findacar.shtml

U.S. Department of Transportation (DOT). (2014). Highway statistics 2014: Table VM-1, Annual vebicle distance traveled in miles and related data - 2014 (1) by bighway category and vehicle type. Retrieved from http://www.fhwa.dot.gov/policyinformation/ statistics/2014/vm1.cfm

Uva, W.-F. L. (2002). An analysis of vegetable farms' direct marketing activities in New York State. Ithaca, New York: Department of Applied Economics and Management, Cornell University. Retrieved from http://EconPapers.repec.org/ RePEc:ags:cudarb:122632

Wallgren, C. (2006). Local or global food markets: A comparison of energy use for transport. Local Environment, 11(2), 233-251. http://dx.doi.org/10.1080/13549830600558598

Wang, Z., Coyle, W. T., Gehlhar, M., \& Vollrath., T. (2000). The impact of distance on U.S. agricultural exports: An econometric analysis (Miscellaneous Publication No. 1566). In W. T. Coyle \& N. Ballenger (Eds.), Technological Changes in the Transportation Sector: Effects on U.S. Food and Agricultural Trade: A Proceedings (pp. 71-83). Washington, D.C.: USDA, Economic Research Service. Retrieved from http://www.ers.usda.gov/ publications/mp-miscellaneous-publication/ mp1566.aspx 
Wooldridge, J. M. (2010). Econometric analysis of cross section and panel data (2nd ed.). Cambridge, Massachusetts: MIT Press.
Wooldridge, J. M. (2012). Introductory econometrics: $A$ modern approach (5th ed.). Mason, Ohio: SouthWestern, Cengage Learning. 